\title{
Prescribing Outside-Work Behavior: Moral Approaches, Principles, and Guidelines
}

\author{
Muel Kaptein ${ }^{1}$ \\ Published online: 24 May 2019 \\ (C) The Author(s) 2019
}

\begin{abstract}
The more the distinction between professional and private life blurs, the more it becomes relevant whether employers may prescribe how employees should behave outside work. By analyzing different moral approaches found in the literature, this article introduces and develops the Integrity Approach to answer this question. Using this approach, an ethical principle for prescribing outside-work behavior is proposed: employees should behave outside work in such a way that they do not disrespect the integrity of their work. This principle is operationalized into twelve guidelines for employers prescribing outside-work behavior for their employees. This article opens up opportunities for follow-up research on the underexamined topic of outside-work behavior from an ethics perspective.
\end{abstract}

Keywords Ethics · Outside-work behavior · Integrity theory · Code of conduct · Principles

On October 2017, 50-year-old Juli Briskman, an employee of a US technology solutions and products firm, was on her daily cycling routine. As she was contemplating the bad state of her country and feeling frustrated about its president, Mr. Donald J. Trump himself passed her in his motorcade. She gave him her middle finger as a sign of protest. A photographer captured this moment and the picture immediately went viral. When her friends tagged her on the photo, she informed her employer about it and was promptly fired (Hauser 2017).

From a business ethics perspective this is an interesting real-life case. Briskman did not do anything illegal and was not at work when she made the gesture. Why then did her company take disciplinary action against her for behavior that took place outside work? Outside work is outside of work's scope, isn't it? However Briskman's boss justified her dismissal by claiming that she had violated the company's code of conduct that states, "Covered Social Media Activity that contains discriminatory, obscene, malicious or threatening content [...] or similar inappropriate or unlawful conduct will not be tolerated" (Hauser 2017). Briskman was totally

Muel Kaptein

mkaptein@rsm.nl

1 Rotterdam School of Management, Erasmus University Rotterdam, Room T11-51, P.O. Box 1730, 3000 DR, Rotterdam, The Netherlands 
unidentifiable in the photo because it was taken from behind, and nothing in her outfit could connect her to her work or employer. Even when she was tagged, there was nothing on her personal social media accounts that linked her to her employer. What then is the ethical ground for her employer to discipline her in this case? Is there any ethical ground at all?

The Briskman example raises a more fundamental ethical question: whether companies and other types of organizations are ethically permitted to prescribe how their employees should behave outside work and consequently, to monitor and discipline them. For example, is it ethically permissible or even desirable for employers to prohibit their employees from privately owning shares of other organizations, from making appointments to meet each other outside work, from privately buying the competitors' products, from engaging in sideline activities; or to require employees to transfer to the organization all earnings from sideline activities, to live safe and healthy private lives, to only speak positively about their organization, and/or to always be traceable, reachable, and available? More specifically, is it ethically permissible or even desirable to prohibit employees from using their phones while driving, from smoking, from visiting sex clubs, from practicing a certain religion, from engaging in dangerous sport activities, from becoming addicted, and from incurring private debts outside work? Or is it better if an employer exercises restraint or altogether refrains from prescribing how its employees should behave outside work?

This article addresses the question whether employers should prescribe how their employees should behave outside work and, if so, what the content should be of that prescription. Following this approach, we explore the moral responsibilities and rights of employees regarding their outside-work behavior (cf. Berkley and Watson 2009). Because this question has not been addressed extensively in the business ethics literature, we mainly refer to literature from the legal profession and public administration fields to identify and discuss current approaches about prescriptions of outside-work behavior. I also introduce another approach, the Integrity Approach, and use this to formulate a principle that employers can use for prescribing how employees should behave outside work: employees should not behave outside work in such a way that they disrespect the integrity of their work. To make the principle more concrete and applicable in the employer-employee relationship, the principle is operationalized into twelve guidelines. To begin, I will define outside-work behavior.

\section{Definition of Outside-Work Behavior}

Outside-work behavior (from here on, OWB) has received scientific attention under many different names: as private behavior (Althoff 2000; Clor 2000; Geraghty 1997; Thompson 1987), private-time behavior (Lasthuizen et al. 2011), personal behavior (Jennings 2005; McDonald and Thompson 2016), off-duty behavior (Pagnattaro 2004), off-the-job behavior (Kossek and Block 1993), out-of-uniform behavior (Miller 2006), unofficial behavior (Grossman and Yalof 1998), non-work behavior (Jacobson and Tufts 2013), outside-workhours behavior (McDonald and Thompson 2016), nonworking hours behavior (Pagnattaro 2004), nonprofessional behavior (Rhode and Woolley 2012), extra-professional behavior (Howard 1975), out-of-classroom behavior (Carlton 1973), off-field behavior (Kosla 2001), and as leisure activity (Olivier 2006). In this article, the term outside-work behavior is used to cover all behaviors of employees when they are not at work and not working for their employer. Outside work is a common term in scientific studies on employee's health (Nylén et al. 2007), ergonomics (Loudoun 2008), and engagement (Bakker and Demerouti 2008). Outside work concerns the time 
for which the employer does not pay the employee, when the employee is off work and does not act on behalf of the employer (cf. Althoff 2000). OWB can include both private behavior (e.g., voting during political elections) and public behavior (e.g., being a member of the town council). However, the term excludes working from home, attending business meetings outside work premises, and doing private activities at the workplace. Under OWB are included potential grey zones such as commuting to and from work, attending social events with colleagues or business partners after work hours, performing sideline activities, and having time off during work trips. Also categorized as OWB are the off-duty behaviors and non-work related activities distinguished by Jacobson and Tufts (2013). The term of choice is "outside-work behavior" rather than "outside-work misbehavior" because it is quite possible that an OWB that is not a misbehavior as such becomes one in the context of work (cf. Menkel-Meadow 2001; Sawicki 2009).

The topic of OWB has received attention in many different work settings, such as professional sport (Kosla 2001), police (Lamboo 2010), education (Carlton 1973), and health care (Sawicki 2009). Relatively much attention has been paid to the OWB of politicians (Dobel 1999; Grossman and Yalof 1998; Thompson 1987), public sector employees (Jacobson and Tufts 2013; Menkel-Meadow 2001; Miller 1997; Miller 2006), and of legal professionals, such as attorneys and lawyers (Althoff 2000; Camarena 2001; Geraghty 1997; Howard 1975; Meadows 1993; Rhode and Woolley 2012). However, little attention has been paid to this concept in the business ethics literature. Donaldson and Dunfee (1999), Vardi and Weitz (2004), and Treviño et al. (2014) focus on ethical and unethical behavior of employees, thereby focusing exclusively on behavior at work. Attention for OWB comes mainly from studies on the conflicts of interests between employees and their employer: e.g., Carson (1994), Dalton and Daily (2001), and Lansing and Goldman (1996). These studies are represented in one of the approaches discussed below. This article focuses on the business work setting using literature on other work settings.

OWB has been studied both for behaviors in general and for specific behaviors. Many of the studies focused on specific types of behavior, like drug use (Greenfield et al. 1989), alcohol consumption (Howard 1975), smoking (Warner 1994), romantic relationships between employees (Binetti 2007), sexual misbehavior (Carlton 1973; Miller 2006), domestic violence (Camarena 2001; Geraghty 1997), social media use (Jacobson and Tufts 2013), misconduct in operating a motor vehicle (Meadows 1993), weight restriction (Cohen and Cohen 2007), and practicing dangerous leisure activities (Olivier 2006). By focusing on OWB in general - like Miller (1997) and Nwabueze (2009) - this article hopes to also cover a variety of specific OWBs.

OWB has also been studied from both a descriptive and normative perspective. Especially legal studies on OWB have taken a descriptive perspective: for example, Meadows (1993) analyzed different legal cases on the grounds for disciplining lawyers who committed misconduct while operating a motor vehicle. Some studies have taken a normative approach: e.g., Binetti's (2007) suggestions for anti-nepotism policies, Dobel's (1999) proposed guidelines for assessing the private lives of officials, and Thompson's (1987) criteria for what constitutes the private life of a public official. This article takes a normative stance by proposing a principle and some guidelines for OWB.

\section{The Growing Interest for Outside-Work Behavior}

The interest on outside-work behavior is not new. For example Plato, Hegel, and Marx already thought about whether politicians should have a private life (Thompson 1987). For lawyers, the scope of inquiries into the private lives of politicians has had "an accordion-like existence 
in American history, opening and closing in relation to larger political and social forces" (Menkel-Meadow 2001: 370). For companies, Bosch (2003: 639) reminds us that "at the beginning of the twentieth century, major American companies had entire departments staffed with hundreds of 'sociological specialists' who were charged with monitoring the private behavior of company employees - often in their homes - to make sure they did not drink too much, had appropriate sex lives, kept their houses clean, and used their leisure time properly." Kossek and Block (1993: 143) even argue that the interest on outside-work behavior is "as old as the system by which people earn a living by working for others."

Several studies have pointed out that OWB is even more relevant today than it was in the past (Binetti 2007; Bösch 2015; Boyd 2010; Olivier 2006) due to the blurring of the lines between work and private life of employees (e.g., Sprague 2011). Work and private have become more interwoven (Hyman et al. 2003) because of changing relationships between employers and employees, growth of flexible work arrangements, homeworking, and the capacity of the Internet and mobile technologies to facilitate these practices (McDonald and Thompson 2016). Employees increasingly do private things at work, but they also work more when at home (Baxter and Kroll-Smith 2005). The distinction between what is work and private has become less clear, leading to all kinds of new issues and risks. For example, RabinMargalioth (2006) notes that personal and even romantic relationships between colleagues within an organization and between employees and clients become more likely.

Employees' outside-work activities are also becoming more public due to increasing transparency. Mass media (Bösch 2015) and social media (McDonald and Thompson 2016) make the visibility of what employees do when not at work quicker and longer. People make their private lives more public, and this publicly available information can be easily related to their work. Their OWB can also nowadays be easily traced because of the manifestations and traces on the Internet, electronic surveillance, and linking of data sources. Sprague (2011) warns that cyberspace offers employers the possibility to invade the social networks of employees. McDonald and Thompson (2016) pointed out prospective employers' practice of asking a job applicant to provide the password to his/her social media account so they can evaluate it. This increasing transparency stimulates more transparency because, as Bösch (2015) argues, the more we know what employees do outside work, the more we know about their misconduct outside work, and the more we want to know what they do outside work.

\section{Current Approaches}

We can find in the literature different arguments for when it is ethically allowed to discipline people at work for their behavior outside work. We can use these arguments to answer the question whether employers are ethically allowed to prescribe OWB, and if so, which specific OWBs. These arguments can be categorized into different approaches, each proposing a different principle for when it is morally allowed for employers to prescribe OWB for employees. We first briefly discuss seven approaches and then discuss more extensively an eighth: the Integrity Approach. Table 1 summarizes the eight approaches.

\section{Employee's Rights Approach}

The Employee's Rights Approach, which holds that employers may not prescribe any OWB because employees have the right to decide for themselves what to do outside work. Outside of 
Table 1 Approaches for the ethical permissibility of prescribing OWB for employees

\begin{tabular}{ll}
\hline Approach & OWB principle \\
\hline Employee's Rights Approach & $\begin{array}{c}\text { The behavior of employees outside work should not negatively } \\
\text { affect how they are treated at work. } \\
\text { Employees should behave outside work in such a way that this } \\
\text { does not negatively affect their actual performance at work. } \\
\text { Employees should not put themselves in any outside-work situation } \\
\text { that would increase their risk of behaving unethically at work. } \\
\text { Employees should behave outside work in such a way that this } \\
\text { does not make them function less competently in their work. } \\
\text { Employees should behave outside work in such a way that this } \\
\text { does not negatively affect their employer's and its stakeholders' } \\
\text { trust in them or in their work. } \\
\text { Employees should behave outside work as they have agreed with } \\
\text { their employer. } \\
\text { Employees should behave outside work in such a way that they } \\
\text { do not disrespect the core values of their work. } \\
\text { Employees should behave outside work in such a way that they } \\
\text { do not disrespect the integrity of their work. }\end{array}$ \\
Integrity Approach &
\end{tabular}

work is out of work's scope, and employees should be free (in their actions and beliefs) from any interference or judgment of their employer. Pagnattaro (2004) calls this the "It's none of your business" perspective. Hence, in this approach, what employees do outside of work should not negatively affect how they are treated at work.

An important argument of this approach is that like any person, employees have a moral right to privacy, that is, they have the right to a "private life, free from the prying eyes, ears and publications of others" (Chadwick 2006: 128). DesJardins and Duska (1987) argue in their article, "A defense of employee rights", that employers testing their employees for drug use is rarely justified because an employee has a right to privacy. They claim that employees have the right to their outside-of-work life remaining their own private concern and that no employer has the right to invade that sphere. Other scholars stress the importance of the protection of other rights. For example, Boyd (2010) argues that romantic relationships between employees within the same organization are ethically permissible because these are expressions of the right to freely associate with others.

Some proponents of the Employee's Rights Approach claim that the autonomy of employees is their most important right. Lippke (1989) argues that there should be restrictions on employers gathering information about their employees' lives because privacy (defined as control over some information about us and over who can experience or observe us) is valuable for autonomy (defined as our capacity to make rationally reflective choices about our ends and activities). Lippke gives two reasons why privacy is valuable for autonomy. First, without control over the information about themselves, people cannot determine their own lifeplan: the lack of control will narrow their own exploration and examination of their lives. Privacy allows people to engage in self-reflection and evaluation of their deepest convictions or most fundamental aspects of their life-plans without intrusion and distraction. Second, individuals subjected to invasions of their privacy seem less likely to conceive of themselves as worthy of autonomy. Lippke cites Kupfer on this matter: "Privacy is a trusting way others treat us, resulting in a conception of ourselves as worth being trusted" (p. 43). Olivier (2006) also finds autonomy important and argues that people may engage in dangerous leisure activities if they want. However, unlike Lippke, Olivier does not make an explicit link between 
autonomy and privacy. Instead, he argues that autonomy is important because freedom is the basis of morality, and mature and rational human beings value their freedom to construct, refine, and/or alter their preferences and life plans. To treat people as autonomous beings is to respect their freedom to make their own decisions, even when they deliberately choose activities that might be harmful. Olivier considers coercion and the threat of sanctions as paternalistic and obvious threats to autonomy. The above arguments on the importance of employees' rights imply that employers should not prescribe OWB at all.

\section{Actual Performance Approach}

The Actual Performance Approach holds that employees are free to do what they want to do outside work as long as it does not negatively affect their actual work performance, and if it does, then employers may interfere even if that behavior is legal and ethical. "It is our business when it affects our business" is how Pagnattaro (2004) labels this perspective. In this view, employers are ethically permitted or even obligated to prescribe that their employees not do anything outside work that would negatively affect their actual work performance. When the OWB has no negative effect, then employers may not interfere.

The basic argument by proponents of this approach is that OWB may influence job performance and thus it becomes relevant for employers. As Bosch (2003: 640) states, "Employers have a vested interest in controlling those aspects of employees' lives that reasonably affect the employees' performance on the job." Employers may expect their employees to do their best to perform well in their job and anything that hinders this should be avoided because of the "employer property interest argument" (Bosch 2003): employers built the factory, bought the machines, and are paying the wages of those who operate the machines; therefore employers should be able to decide who operates those machines in their factories. If this argument is unconditionally accepted, then there can be no restrictions on the right of employers to hire and dismiss employees. For Bosch, employers may take action when there is sufficient evidence that there is substantial negative impact on their legitimate or true business interest.

Under this approach, OWB becomes a relevant concern for work when there is a nexus of conduct, i.e., there is a connection between OWB and behavior at work. Meadows (1993) refers to this as the nexus theory, and Miller (1997), as the nexus submodel. Howard (1975) argues that when there is no logical relationship or nexus between an attorney's OWB involving alcohol and sex and his job performance, then the bar should not discipline him. Menkel-Meadow (2001: 378) states that, at least for the U.S., "The touchstone of all scrutiny of private life in the occupational sector has always been the relevance or nexus of private action to job performance." Cranford (1998) considers setting demands on OWB not only normal but also justified. For instance, employers may rightfully expect that employees dress well and start work on time. These expectations place limitations on an employee's OWB, such as traveling time and expenses, and time and money spent to shop for work attire.

The proponents of the Actual Performance Approach do not necessarily ignore that employees have rights of privacy and autonomy. They can in fact even support the performance approach because they want to protect the rights of employees. They do this by suggesting that employers may only prescribe norms for OWB if these have to do with employees' work performance and that interference is impermissible for as long as the employee performs well. Bosch (2003) follows the same line of reasoning in his article, "None of your business (interest): The argument for protecting all employee behavior with no 
business impact." However, we can still group scholars who explicitly or implicitly give precedence to business interests over the protection of employees' rights (even if they recognize the latter) under the performance approach. For example, Pagnattaro (2004) develops guidelines for limiting the use of employees' OWB as the basis for adverse employment actions. By acknowledging the rights of employees, Pagnattaro suggests that the business interests of employers are limited. However, she also claims that "off-duty behavior. .. should only subject the employee to adverse employment action if the activity has some effect on the employer" (p. 382). This opens the door for violations of employees' rights. Cranford (1998) also defends the employee's right to privacy with regard to drug testing but at the same time, he argues that this right is not violated when the employer collects employees' personal information that is relevant for that employer. Both Kossek and Block (1993) and Rowan (2000) argue that while employees have a right to privacy outside the workplace and that employers should act conservatively in invoking mandatory policies that affect employees' personal lives, it is acceptable for an employer to take action when the OWB of employees leads to a decline in their job performance. Therefore, employers have the right, as Mael puts it (1998: 196), "to protect the organization from employing destructive persons."

\section{Conflict of Interests Approach}

For the Conflict of Interests Approach, OWB is relevant not when it affects the performance at work but when the situation outside work increases the risk of unethical behavior at work. The situation outside work is seen as predictive of behavior at work. Thus by regulating these kinds of situations, employers address potential unethical behavior in advance. In this sense, this approach is more proactive than the previously discussed Actual Performance Approach because in the latter, the employer will only intervene when the performance of the employee starts declining. According to the Conflict of Interests Approach, employees should therefore not put themselves in any outside-work situation that increases the risk that they will behave unethically at work.

The main idea of this approach is that employees should not have interests outside of work that may conflict or may seem to conflict with their employer's interests. The standard conception of a conflict of interests - as used in the Agency Theory (Eisenhardt 1989), advanced by Davis (2001), and elaborated by Coleman (2005) - applied to OWB postulates that employees (as agents) are ethically required to exercise judgment on behalf of their employer (the principal) but that employees have an (special) interest that tends to interfere with the proper exercise of that judgment; as a result, their judgment is less reliable than it would normally be. In a conflict of interests, the employees' ethical obligation to act in the interests of their employer tends to be unduly influenced or even dominated by an interest that they have outside of their work (Boatright 2001). When there is a conflict of interests, there is "reason to worry" (Borden and Pritchard 2001: 79) that the judgment and performance may be compromised, without suggesting or presuming that the decision is necessarily compromised. Examples of such conflicts of interests are engaging in sideline activities (risks neglect of duty at work), privately owning shares (risks misusing information of one's employer in trading these shares), and moving in criminal circles (risks being put under pressure by criminals to behave unethically at work). Davis (2001) views conflict of interests as a moral problem because it is a tendency to be biased, and it is objectionable if people do not respond to it adequately. Davis considers even an apparent conflict of interests as objectionable because it misleads others. Rabin-Margalioth (2006) can also be considered as an adherent of this 
approach. She argues that romantic relationship at work is good for business and therefore should be welcomed as long as there is no conflict of interests - i.e., one of the couple does not have supervisory authority over the other. A conflict of interest is not objectionable because employees misuse their position; it is objectionable because it increases the risk that they will (seem to) misuse their position. With regard to this, Pagnattaro (2004) proposes a provision for the law that employees, despite their rights, should not create outside work an actual or potential material conflict of interests that affects their employer's business interest.

\section{Good Competences Approach}

The Good Competences Approach, also called "the good character requirement" by Woolley (2007), focuses on the competences or character employees show outside work and not on the outside-work circumstances as the predictor of unethical behavior at work. When employees display a lack of a competence outside work and this competence is relevant for their work, this is evidence that they are less fit or even unfit to perform their work; this then allows or even requires employers to interfere. This approach proposes that employees should not show outside work a lack of any competence that is relevant for them to perform their work well.

The central idea of this approach is that OWB may reveal weaknesses in the competencies of employees; and if these competences are relevant for work, then OWB becomes relevant for employers. For example, an employee who without reason regularly beats his children shows that he is an aggressive person. If aggression is an undesirable trait for performing his work well, then the employee is less fit or even unfit for his work. The assumption is that people have one character, or at least they do not have two completely different or inconsistent characters, one at work and another outside work. This is the line of reasoning of both Plato's and Aristotle's virtue ethics theory, which considers all behavior, regardless of whether it is private or public, to manifest the same underlying moral character. Althoff (2000) also follows this approach in arguing that lawyers are publicly and privately one person. Rhode and Woolley (2012) presuppose this view when they argue that lawyers should not privately behave in such a way that it may undermine their ability to practice their function. Such behaviors make them unfit and less competent for their job, even if it is difficult to predict whether and how their lack of competences will manifest in their work. For Rhode and Woolley, the advantage of this perspective is that not all behavior that reflect a defect are relevant; only those that reflect a defect in work-related competences are. Carlton (1973) similarly argues that it is not the fact that out-of-classroom sexual misconduct is a criminal behavior that makes someone unfit to teach and thus a ground for revocation of teaching credentials. It is because this crime proves that someone has a defect of character that impairs their professional ability to teach and thus makes that person unfit to teach. Jennings (2005) is a strong adherent of this approach. In analyzing companies that were faced with scandals, she suggests that all CEOs and CFOs of these companies also misbehaved privately (e.g., engaged in adultery, marijuana use, and being photographed with scantily clad dancing girls). She claims that if someone misbehaves privately then that person also misbehaves at work because private misbehavior is a measure of moral development. If people treat those who are closest and most important to them - i.e., family - with disregard and breaches of trust, it is not a leap in logic, according to Jennings, that the same character can be dishonest with those at work, who are not even acquaintances. Woolley (2007: 76) warns that although she advocates the Good Competences Approach, it is not an assurance that employees - in her case, lawyers are actually of good moral character: "It is an attempt to ensure that no lawyers with obvious, 
relevant and unremedied flaws of character, flaws which make them currently unfit for legal practice, are admitted."

\section{Moral Discredit Approach}

For what I call the Moral Discredit Approach, outside work circumstances, personal competences, or work performance is not the ground for defining what kind of OWB is unacceptable; it is the reputation of and trust in the employer. This approach holds that employees should not behave outside work in such a way that it brings moral discredit to their work and thereby damaging the trust of stakeholders in the employer or in the employee. Thus, OWB is only problematic when it becomes known within or outside the organization and when those who know about it consequently disapprove of it. The approach thus advocates that employers should not interfere in their employees' OWB as long as these remain private.

In this approach, the reaction of stakeholders is relevant. Howard (1975) describes how moral turpitude, which is the amount of publicity and public reproach involved in the case, has been used as a ground for disciplining attorneys for their OWB. Kosla (2001) argues that sport professionals should not bring their sport into disrepute even when they are off the field or even when their ability to engage in the sport is not impeded. Off-field misbehavior may be injurious to a sport because a particular standard of behavior to which an individual himself subscribes (or has been subscribed to via a sport's governing body) has been diminished in the eyes of the public. Whereas Kosla stresses that sport professionals are role models and should therefore not misbehave off field, in the Moral Discredit Approach, it is relevant for employers to prescribe OWB when employees in their outside-work behavior can disrespect public opinion or damage trust. For this reason, Sawicki (2009) calls this approach the trust theory. For Geraghty (1997), when arguing why domestic violence committed by attorneys is relevant for their work, the crux is that this behavior shows moral indifference to the opinion of the community, and instead of respecting, they dishonor the public opinion. Attorneys should therefore, according to Geraghty, not be "bruising the legal profession" (p. 451). Whereas Clor (2000) argues that people should not do what the public disapproves, Geraghty argues that not everyone's opinion counts; only of those who are informed and engaged. Nwabueze (2009) follows this same view when he argues that disciplinary tribunals should focus on cases involving moral turpitude because these cases are breaches of trust. Jacobson and Tufts (2013) and Miller (1997) also think that employees should not suggest that they are at work when in fact they are not - e.g., by using social media and workwear - because this can mislead others and bring discredit to their organization. Seymore (2003) argues that to protect and preserve the trust of society in the profession, a lawyer should not have sexual relations with a client. For Althoff (2000: 105), using moral turpitude as a criterion to discipline the OWB of lawyers is useful because, although the concept is not easy to apply and appears too vague and uncertain to some, it is "wonderfully flexible and responsive to the changing needs of society to identify certain conduct which, even though not clearly delineated in advance, all members of society should understand will simply not be tolerated by a member of a privileged profession."

\section{Market Contract Approach}

Another approach is the Market Contract Approach. This approach holds that employers should not unilaterally impose prescriptions for OWB on their employees, but that they should have an agreement with their employees about these prescriptions. Once agreed and 
established in, for example, an employment contract or code of ethics, employees should comply with these agreements and so should their employer, too.

Under this approach, prescriptions for OWB are negotiable and should be voluntarily agreed upon in mutual exchange. Employers and employees should only agree when it is profitable for both. Menkel-Meadow (2001) argues that by taking and accepting a function, one also accepts the privacy sacrifices that accompany it. She gives as examples the President of the United States (whose job is 24/7 and thus always public), and astronauts in orbit (who, by having taken this job, make themselves available to be publicly scrutinized for their private behavior). Employees accept their job because the benefits of the job outweigh how much privacy and autonomy they have to surrender as a result of the restrictions on their OWB. In this positive neoclassical economics line of reasoning (Bosch 2003), employers will only pose additional restrictions on OWB if these restrictions are in their interest and outweigh the additional salary or other provisions they have to offer to make it attractive for employees to accept the job. However, if the prescriptions are too restrictive or not sufficiently compensated for, then in terms of supply and demand, employers have to loosen the restrictions on OWB or offer more compensation until they get the appropriate person to do the job. Davidson (1998: 160) calls this approach "the marketbased alternative to legal protections of employee privacy." It is important, as Bosch (2003) notes, that agreements can only be valid when the market functions well and that employees are autonomous in the sense of being free from coercion and having several real options.

\section{Core Values Approach}

A final approach derived from the current literature on OWB is the Core Values Approach. The core values of an organization are essential for its good functioning, and every employee needs to adhere to and support these. When employees demonstrate that they do not understand and respect these values either in their work or outside work, then they are not fit to work for the organization. This approach therefore holds that employees should not do anything outside work that disrespects the core values of their employer.

Sawicki's (2009) core values theory advances this approach. She focuses on physicians being disciplined by medical boards and argues that OWB is relevant when it implicates any of the core professional values of medicine. Only physicians whose OWB shows disrespect for those values should be disciplined. For Sawicki, the relevance of disciplining OWB is not because OWB may predict behavior at work but because it is unacceptable when OWB ignores any of the core values that physicians should uphold in their work. Someone who outside work violates a core value of his work shows that he fails to understand that value. Because OWB that violates non-essential or aspirational professional values is not a matter for discipline, the ethical demands on the OWB of physicians are thus realistic for them to meet. Meadows (1993) similarly argues that attorneys should be disciplined for OWB that violates the law (in this case, traffic laws) because as officers of the court, attorneys should also respect the law even in their private lives and even if such misconduct does not directly adversely reflect on their professional abilities.

\section{The Integrity Approach}

Having identified and discussed seven approaches, we can now briefly evaluate them. The appeal of the Employee's Rights Approach is that it is straightforward: it fully takes the side of 
the employee; employers should fully respect the employees' privacy and autonomy and not interfere at all in their OWB. However, this approach ignores the interests and rights of the employer and of its other stakeholders whose interests can be damaged by the OWB of employees. The Actual Performance Approach takes care of this shortcoming by honoring the rights of employees unless their OWB evidently and substantially negatively influences their performance at work, in which case, the employer may then interfere. However, this approach is empty in the sense that mere decline in work performance is already a ground for employer interference in employee's OWB (DesJardins and Duska 1987). This Actual Performance Approach also subordinates the rights of an employee to good work performance. This would, for instance, unjustly allow an employer to prohibit an employee from becoming pregnant because she would not be able to work at all during her maternity leave. The strength of the performance approach is that it only permits employer interference when OWB evidently leads to substantially lower work performance. Thus as long as there is no clear business interest being harmed, the employees' rights take precedence. The Conflict of Interests and Good Competences Approaches are both based on prediction: i.e., prescribing OWB is relevant for employers when OWB might lead, sooner or later, to unethical behavior at work. The strength of these prediction approaches is that employers focus on preventing issues from arising, while in the performance approach, employers may only take action when there are already issues resulting from OWB. However, the Conflict of Interests Approach demands a lot from employees because by proposing that employees should not create situations where there is a conflict of interests, employees are expected to sacrifice any interests that conflict, actually or potentially, with their work. Menkel-Meadow (2001) and Sawicki (2009) criticize the Good Competences Approach because its presupposed predictive power has not been convincingly empirically demonstrated.

The strength of the Moral Discredit Approach is that it considers the moral consequences of OWB as most important. It urges employees to take care that their OWB will not lead to negative publicity for their employer and for themselves at work. This approach has several weaknesses. One is that because public opinion is the yardstick that evaluates the consequences of an OWB, this creates the danger that "morality falls into the hands of the illogical and ill-informed" (Driver 1992: 336). In response to this criticism, Geraghty (1997) suggests narrowing the "public" to include only those who are well-informed and engaged. This approach also implies that for as long as no one finds out, then from the perspective of the employer, the OWB is ethically allowed. For example, it is not a problem for a company if its CEO privately trades shares of the company's competitors as long as this stays secret or not publicized. Another weakness is that if regulating employees' inappropriate OWB will damage the reputation of the organization - for example, because such action will suggest to the public that employees are actually or possibly participating in inappropriate behaviors - then this possible damage to the organization's reputation is a legitimate reason not to constrain inappropriate OWB at all (cf. Seymore 2003). In the case of the Market Contract Approach, one of its advantages is its open and flexible construction: i.e., any OWB can be constrained but only as long as both the employer and the employee agree. In addition, the idea that employees should get sufficient compensation for sacrificing their rights is also appealing because it underscores that regulating OWB necessarily comes with obligations on the part of the employer. However, scholars like DesJardins and Duska (1987), Bosch (2003), Seymore (2003), and Rabin-Margalioth (2006) are critical of this approach's viability. They argue that the required level-playing field for any agreement is often missing because employers are more powerful than employees. 
The Core Values Approach has two strengths: it limits the prescription of OWB to the type of behavior the organization values most, and it avoids the complexity of the prediction approaches by considering an OWB unacceptable when it disrespects the values of the employer. A weakness of this approach is that it can be very demanding because it implies that employers may prescribe that their employees respect not only the employer's core moral values but also the amoral ones. For instance, Star Bank and Danske Bank have agility as one of their core values. Does this mean that it is reasonable to prescribe that one's employees should be agile in their OWB? This leads to the otherwise ridiculous conclusion that employers may prohibit their employees from being relaxed and passive outside work. The same holds for amoral values like entrepreneurship, innovativeness, and efficiency. We can avoid this unwanted conclusion by limiting prescription of OWB to only the moral core values of the employer. However, this is still problematic. If honesty is an employer's core value, then according to this approach, employees should be required to never tell a lie in their private life; or if compliance is a core value, then employees should be required to never commit a traffic offense. The Integrity Approach for OWB prescriptions meets these objections against the Core Values Approach without giving up its advantages.

\section{Elements of the Integrity Approach}

The concept of integrity derives from the Latin term integritas, meaning wholeness. Wholeness does not only imply being unbroken, undivided, untarnished, and incorruptible; it also has a positive meaning: to be pure, coherent, intact, and of one piece (cf. Benjamin 1990; Maak 2008). Integrity is standing for something (Calhoun 1995) or loyalty in action to values (Becker 1998). Values can be morally justifiable because they should generally apply to everyone in the same position (Becker 1998) or apply only to a group or an individual when they concern identity-conferring commitments (Williams 1981; Kekes 1983). These commitments are aimed at one's own values, give moral identity, and cannot be dismissed without self-betrayal. They are constitutive of who one is as a person, as a professional, and as an organization (cf. Musschenga 2002). As McFall (1987) puts it, integrity assumes identityconferring commitments because everyone needs to define values about who they are. The Corporate Integrity Theory developed by Kaptein and Wempe (2002) aims to protect the integrity of the business organization, that is, to protect that the organization is not broken and remains whole. An organization remains whole when employees in their behavior are loyal to the values that generally apply to and are constitutive of the identity of their organization. When employees behave such that they disrespect these values, they then violate the integrity of the organization.

An Integrity Approach helps clarify why OWB is relevant for organizations. An employee is not just the sum of its individual roles and functions, with each role and function having its own compartmentalized moral values. Integrity is about having an integrated life, a life that is whole. As MacIntyre (1999: 318) states, "integrity requires of those who possess it, that they exhibit the same moral character in different social contexts;" or as Dobel (1999: 4) says, "Integrity assumes a oneness or unity in the moral life of individuals." It is concerned with having a stable set of values (Benjamin 1990). Hence, integrity is about the values that unite the different inside-and outside-work roles and functions of employees; if there is no unity or wholeness in the values to which one is loyal, then there is no integrity. In this sense, we can understand why Althoff (2000: 105) claims that lawyers "need to be whole and complete" for their entire life. So when employees show outside their work that they identify with values that 
are inconsistent with the values of their employer, then they do not only show that they personally lack integrity but also that they disrespect the integrity of their employer because they do not really identify, as a person and as an employee, with these organizational values.

Not every OWB that is inconsistent with the moral values of one's employer is a violation of its integrity. An OWB violates an employer's integrity when the OWB expresses a flaw in the integrity of the employee. After all, integrity is actor-based and not action-based (Kaptein and Wempe 2002). This flaw in integrity is relevant not because it is predictive of future work behavior, but because with this flaw the employee is disrespectful towards the values. It is not only his behavior that fails; he also fails as a person because he $i s$ not loyal to the moral values of his organization. Take for example an employee who works for an organization where compliance is an important core value and who drives too fast outside of work. This behavior is as such not a violation of the organization's integrity. It becomes one when this traffic violation is due to his lack of integrity, say, he does not care about laws. Attribution theory (Lord and Smith 1983) is useful in determining whether a behavior is a result of character. Whether someone does not care about traffic laws can be seen, for example, in the frequency of traffic violations and the extent to which he drives too fast. There is a difference between someone who drove five miles too fast only once and someone who regularly drives fifty miles over the speed limit.

From an integrity perspective, we can now distill the following principle for employers to use for prescribing their employees' OWB: employees should behave outside work in such a way that they do not disrespect the integrity of their work. When employees show in their OWB that they are not loyal to one or more of their employer's moral values, then they are not whole and thus lack integrity. In this sense, the demands on the OWB of employees are not onerous: they do not concern all values but only the moral values of their work; they are not about OWBs that do not demonstrate the moral values of their work but only those OWBs that violate these values; and they are not about all OWBs that violate the moral values of their work but only those that show that employees do not identify with these values.

\section{Guidelines}

Now that we have determined the principle for OWB from an integrity perspective, we now explore how to operationalize this principle into more concrete guidelines. The guidelines should not be too detailed so as to avoid the risk of becoming inflexible and to be able to capture changing expectations over time and across various contexts (Sawicki 2009). At the same time, these guidelines should do more than call for a moral dialogue about OWB without giving directions about how to evaluate OWB, as Menkel-Meadow (2001) does. We will see that the proposed guidelines overlap with some of the other approaches, which makes sense due to the integrated nature of the concept of integrity (cf. Kaptein and Wempe 2002). Guidelines 1, 2, and 10 are related to specific values, while the other nine guidelines are related to values that apply to organizations in general. For these general values, I will use the company values proposed by Kaptein and Wempe (2002) and Scott (2002). That the guidelines apply to OWB does not imply that they apply only to OWB; the guidelines may also apply to employees while they are at work and during their working hours.

Guideline 1: Employees should not disrespect outside work those moral values that constitute the identity of their organization As stated above, identity-conferring 
commitments are one source of moral values. This guideline means that employees should not disrespect the moral values that constitute the identity of their organization. For example, it is reasonable that a bank that stands for prudence will prescribe that its employees not play in a casino outside work (when this is associated with extravagance); that an insurer that stands for risk-awareness will prescribe that its employees not make phone calls while driving outside work (when this is associated with recklessness); and that a tax consultancy company that stands for compliance will prescribe that its employees not privately use disputable tax constructions (when this is associated with subversiveness).

Guideline 2: Employees should not disrespect outside work the moral values that constitute the identity of their function Whereas the first guideline applies to everyone working at the same organization, the second guideline applies to everyone holding the same function across organizations. For example, financial auditors or controllers with huge personal debts disrespect the moral value of independence that is relevant for their function (Reiter and Williams 2004); salespersons who privately buy only the products of competitors do not demonstrate that they believe in their own products and as such they disrespect their function; and compliance officers who frequently break the law outside work demonstrate that they do not have the attitude of respect for the law that is essential for their function.

\section{Guideline 3: Employees should not create situations outside work that impair or presume} to impair their objective judgment in their work Conflicts of interests that arise between what employees do outside work and during work are problematic from an integrity point of view when these conflicts indicate that the employees do not take seriously the integrity of their organization and function. These employees are disrespecting the integrity of their work by putting it at risk. This also holds for creating the appearance of conflicts of interests because it indicates that employees do not care that others believe that they are putting their work's integrity at risk. For example, employees who own shares of the competitor provoke the impression that this impairs their objective business judgement because they will privately profit when the competitor performs better than their own company. From an integrity perspective, this is objectionable because it disrespects the value of objectivity (Kaptein and Wempe 2002), even when these employees always make objective business decisions.

Guideline 4: Employees may use their organization's resources for private purposes only with prior consent from the appropriate authority in the organization Employees receive from their employer various means and resources for doing their job, such as equipments, computers, mobile devices, means of transportation, cash, and data. Employees can also have, due to their function, access to all kinds of other resources that they can use for private purposes, such as office space, materials, and products. These resources are the property and assets of the employer. Hence using them for private purposes without proper permission is unacceptable because this disrespects the values of appropriateness and functionality (Scott 2002). Organizations can only function well if employees use the organization's means for the purposes it deems appropriate (Kaptein and Wempe 2002).

\section{Guideline 5: Employees should not carelessly use their organization's resources outside} work Whether or not they have the permission to use organization's resources for private purposes, employees can take home these resources for work purposes. For instance, they can take confidential information and a computer from the office to work at home, use the company 
car to drive between home and work, and use company-provided mobile devices at home so they can be reached for work. Even when they are not at work, employees have the responsibility to handle these resources with care. When they fail to do so, then they disrespect the value of carefulness (Kaptein and Wempe 2002; Scott 2002). This value is important because it prevents unnecessary repair or replacement costs for the organization and delay in work due to damaged equipment. By using organization's means carefully, employees also show that they are aware that they do not own these things. Carefulness is also necessary to prevent organization's means from falling into unauthorized hands. For example, it is reasonable that employers expect their employees to not leave lying around their home confidential information of their employer and to not carelessly dispose such documents without destroying them first.

Guideline 6: Employees should not pretend that they are at work when they are not and misuse this situation for private purposes Miller (1997) describes many examples of government employees who outside work pretended that they were at work and used this for private purposes: e.g., off-duty police officers who put on their uniforms or carry their nightsticks to use their authority to lure citizens and sexually abuse them. This type of OWB is a violation of the integrity of one's organization because it disrespects the value of honesty (Kaptein and Wempe; Scott 2002). This behavior misleads others, as Miller argues, by not making clear what one's role is at that instance: as an employee or as a citizen. In such cases, the OWB is then wrongfully attributed to the organization. Two other examples of OWB that intentionally mislead others are using official company stationery for private purposes and privately engaging in political activities but giving the impression that one is representing one's organization.

Guideline 7: Employees should not use outside work their official function to obtain favorable personal gains Employees are given their function within the organization so they can do what the function requires them to do. Employees misuse their function when they use it instead for other purposes, such as to obtain favorable treatment for themselves, for family members, or for others with whom they have a private relationship. An example of this is asking outside work one of the organization's suppliers to give a discount on one's private purchase of this supplier's products. By behaving this way, employees disrespect the value of loyalty to one's organization and function (Kaptein and Wempe 2002; Schrag 2001).

Guideline 8: Employees should not disrespect outside work their colleagues and their organization's external stakeholders with whom they have a working relationship Integrity entails that employees respect each other's integrity (Audi and Murphy 2006). This implies that at work employees should not, for example, discriminate, intimidate, and harass each other. This holds even outside work because even then they are still colleagues, and a disrespectful behavior between them is a violation of mutual respect and of the organizational value of fairness (Kaptein and Wempe 2002). For the same reason, the organization norms on how employees should treat external stakeholders while at work also apply when they are not at work. Employees' OWB towards the stakeholders will reflect on them as employees and on their organization because their behavior cannot be separated from the business or working relationships they have with those stakeholders.

Guideline 9: Employees should not speak ill of their organization publicly outside work Employees have the right to free speech (Carlton 1973; Kosla 2001; Pagnattaro 2004). However, when they publicly speak ill of their organization outside work, they 
disrespect the integrity of their organization not only by questioning the integrity of their organization (i.e., the object of their speech) but also by disrespecting the value of openness (Kaptein and Wempe 2002). Even when an employee admits that the speech is his personal opinion, by publicly badmouthing his employer, he is suggesting that there is no sufficient room within the organization to address his concerns (which is why he pours it out in public). Only in cases when an employee has tried everything to address the issue internally but failed, then is he ethically allowed to take it up externally. The absence of internal venues for his concerns points to the organization's lack of openness; and if this value is absent or nonexistent, then it cannot be violated. However, the permissibility of whistleblowing publicly does not justify making everything about the organization known to the entire eternal world. Integrity requires that external reporting should be proportionate to the interests at stake and directed to those who can take action so that one still remains loyal to the organization and not become disintegrated as a person (cf. De George 2011; Lindblom 2007).

\section{Guideline 10: Employees should not disrespect outside work the moral commitments} they express in their work Integrity is about keeping oneself to self-committed and selfprofessed values (Benjamin 1990; Dobel 1999; McFall 1987). This implies that employees are obliged to comply with the moral commitments they express in their work concerning their OWB. An employee who lies to his colleagues about doing a lot of personal volunteer work is not whole. This behavior disrespects the value of honesty. The same can be said of the CEO who in his work professes to protect the environment but outside work is a big environmental polluter.

\section{Guideline 11: Employees who observe outside work that a colleague disrespects the} integrity of their organization should initiate corrective action Whether employees are loyal to the moral values of their organization can be seen in, for instance, how they respond when they observe outside work a colleague disrespecting their organization's integrity. When one cares about the integrity of the organization, it should not make any difference whether one observes a violation during work or outside work; the importance of integrity remains the same. Moreover, what one does outside work even proves strongly how much one cares for the organization's integrity: because one is not at work, has greater autonomy, and has more opportunities to just ignore the situation.

Guideline 12: Employees should keep the voluntary agreements they made with their organization about their OWB Integrity is also about keeping agreements that one made voluntarily (Benjamin 1990; Minkler 2008). Breaking agreements opportunistically shows a lack of respect and loyalty, values that are important for organizations (Kaptein and Wempe 2002). Employers are allowed to make additional agreements with employees about OWB, which are not covered by the other guidelines above. For example, agreements can be made about reachability and availability, place of residence, and leisure activities. If, for example, an employee has a physically heavy job and he agrees with his employer that he will not perform other heavy activities outside work, then the employee has to keep this agreement.

\section{Discussion}

This article discussed the ethical dimension of OWB, a topic that has received limited attention in the literature on the moral responsibilities and rights of employees. It is a relevant topic for the 
field of ethics that may become even more important when the transparency of OWB further increases and the lines between professional versus personal further blurs. Based on the current literature, seven approaches were distinguished, each proposing a different principle for when it is ethically permissible for employers to prescribe their employees' OWB. An eighth approach was introduced and elaborated: the Integrity Approach. One of the advantages of this approach is that it does not require empirical evidence about the (potential) effects of OWB on work.

We also operationalized the proposed integrity principle for OWB (i.e., employees should behave outside work in such a way that they do not disrespect the integrity of their work) into twelve guidelines. These guidelines are related to general and specific moral values of business organizations and of functions within such organizations. In this way we answer in the affirmative Menkel-Meadow's (2001) question whether standards for OWB differ for different functions. The twelve guidelines show the broad spectrum of OWBs that employers may prescribe. The guidelines also show that there can be OWB that is not wrong as such but only becomes wrong in relation to work. The guidelines overlap with the other seven approaches discussed above, indicating the integrated nature of integrity (Kaptein and Wempe 2002). The guidelines include many OWBs but also exclude ones that are unreasonable for employers to prescribe. For Sawicki (2009), the latter is an important requirement for a theory about OWB.

An Integrity Approach for prescribing OWB opens many possible directions for follow-up research. Employees should respect the integrity of their organization and employers should also respect the integrity of their employees. What does this respect on the part of employers entail and how should they respect the integrity of their employees? For example, which methods for monitoring employees' OWB are permissible for employers to use from an integrity perspective? Is it permissible that employers use open public sources to assess whether their employees do not disrespect the organization's integrity? So far, standards have been proposed for drug testing (Cranford 1998; DesJardins and Duska 1987). Another research direction is to examine what the desirable or appropriate responses are when an employee has disrespected the integrity of his organization outside work. For example, would disciplining the employee at work constitute unnecessary double punishment (Camarena 2001)? DesJardins and Duska (1987) suggest that the goal of disciplinary interventions is not primarily punishing but preventing future harm. Another research direction is finding out the conditions that make the guidelines more or less important. The conditions that have been suggested to increase the importance of OWB for work are the intimacy of relationships (Seymore 2003), the level of responsibility (Dobel 1999), the extent to which one is a role model (Kosla 2001), exposure to the public (Bosch 2003), whether someone seeks the publicity himself (Thompson 1987), and the moral intensity of the issue (McDonald and Thompson 2016). Other interesting research issues are the extent to which OWB can strengthen the integrity of the organization, how we can evaluate past OWB that becomes known (cf. Dobel 1999; Menkel-Meadow 2001), what increasing transparency and blurring lines mean for the importance of the topic of OWB and what other factors determine the importance of this topic (cf. Kossek and Block 1993), whether there are other guidelines for OWB apart from the ones proposed here, the extent to which employers are morally responsible for their employees' OWB (cf. Miller 2006), and the extent to which employers can promote the integrity of their employees outside work.

More research is also needed to better understand the advantages and disadvantages of the different approaches for prescribing OWB. In this article, the current approaches were only briefly evaluated to be able to position the Integrity Approach. Next to evaluating these current approaches in more detail, the potential disadvantages of the Integrity Approach for OWB also need to be examined. One disadvantage may be the difficulty in its practical application. For 
example, because the proposed Integrity Approach holds that employees should not disrespect the moral values that constitute the identity of their function and organization, it may be difficult to define those values in concrete situations, to operationalize these values into norms, and to reach agreement when there are conflicting interpretations about these values and norms. Because the Integrity Approach holds that an OWB violates the integrity of an organization or a function when it expresses a flaw in the integrity of the employee, it may also be difficult to determine in concrete situations the extent to which a behavior is the result of character. Apart from these problems, an Integrity Approach for OWB may also be problematic from an ethical perspective. For example, the Integrity Approach holds that the constituent moral values of work should not be disrespected. This presupposes that when the constituent moral values of work conflict with the constituent moral values of the employees' identity, the moral values of work should take precedence. If there are situations where it is ethical that the moral values of employees take precedence, then we need to develop guidelines for this and establish if these can be part of the Integrity Approach or if they are part of another approach. The latter implies that more than one approach is legitimate and that we have to develop criteria for selecting which approach for OWB is appropriate in which situation.

\section{Practical Implications}

The main idea of this article is that employers should prescribe to employees the kind of OWB that it expects from them and that employees have the moral responsibilities and rights to keep to these prescriptions. I discussed eight different principles from which employers can choose for doing this, and I operationalized the integrity principle into twelve specific guidelines. In addressing the issue of employees' OWB, employers show that they care about protecting their own integrity and that of their employees. Given the increasing transparency of OWB and the blurring lines between work and private life, the urgency for employers to make a principled decision on this matter becomes more important. Organizations could, for example, address this issue in their code of ethics. Together with including one or more of the proposed guidelines and defining OWB, organizations can further operationalize these guidelines, for instance, by making them reflect the values that constitute the organization's moral identity and what this means for their employees' OWB. A case in point is Toyota's code of ethics: "Toyota also strongly desires that the people working for Toyota, a company engaged in automotive business, are aware of traffic safety and lead safe [...] lives. Regardless of whether at work or in a private situation, we should pay careful attention to traffic safety, obtain basic legal knowledge, and be aware of common social protocol."

Going back to the case of Juli Briskman, what does an Integrity Approach have to say about this case? Briskman did not violate many of the guidelines developed in this article. Her gesture of protest did not create a situation that would have impaired her objectivity in her work because she had no business relationship with the President (Guideline 3), she did not make use of her company's resources (e.g., it was her own bicycle (Guidelines 4 and 5)) and she was not pretending to be at work (e.g., she was wearing sports clothes that did not identify her company (Guideline 6)). Furthermore, she did not use her official function to obtain favorable personal gains (Guideline 7), she did not speak ill of her company (Guideline 9), none of her colleagues were involved (Guideline 11), and she did not violate the code of conduct of her company (even though her superior claimed otherwise, she did not herself post or spread the picture on social media (Guideline 12)). We cannot conclude if Briskman had violated some of the other guidelines because this would depend on facts and information 
about the case that are not publicly available. She would have violated a guideline if, for example, submissiveness was a moral value that constitutes the identity of her company (Guideline 1), or if representativeness was a moral value that constitutes the identity of her function as marketing director (Guideline 2), or if she had admitted at work that she was a big supporter of the President's policy (Guideline 10). Violation of Guideline 8 is, as far as I can establish, most likely. This guideline states that employees should not disrespect outside work their organization's external stakeholders. Although Briskman was not a government employee, her employer was a government contractor. Therefore, Briskman did not only give the middle finger to the nation's president but also to the head of one of her company's clients. In sum, an Integrity Approach raises relevant considerations for not only the rights and responsibilities of employees at work but also outside work.

\section{Compliance with Ethical Standards}

Ethical Approval This article does not contain any studies with human participants or animals performed by the author.

Conflict of Interest The author declares that he has no conflicts of interest.

Open Access This article is distributed under the terms of the Creative Commons Attribution 4.0 International License (http://creativecommons.org/licenses/by/4.0/), which permits unrestricted use, distribution, and reproduction in any medium, provided you give appropriate credit to the original author(s) and the source, provide a link to the Creative Commons license, and indicate if changes were made.

\section{References}

Althoff, B. (2000). Big brother is watching: Discipline for private conduct. In ABA Center for professional responsibility (pp. 81-106) The Professional Lawyer: Symposium Issue.

Audi, R., \& Murphy, P. E. (2006). The many faces of integrity. Business Ethics Quarterly, 16, 3-21.

Bakker, A. B., \& Demerouti, E. (2008). Towards a model of work engagement. Career Development International, 13, 209-223.

Baxter, V., \& Kroll-Smith, S. (2005). Normalizing the workplace nap: Blurring the boundaries between public and private space and time. Current Sociology, 53, 33-55.

Becker, T. E. (1998). Integrity in organizations: Beyond honesty and conscientiousness. Academy of Management Review, 23, 154-161.

Benjamin, M. (1990). Splitting the difference: Compromising and integrity in ethics and politics. Lawrence: University Press of Kansas.

Berkley, R. A., \& Watson, G. (2009). The employer-employee relationship as a building block for ethics and corporate social responsibility. Employee Responsibilities and Rights Journal, 21, 275-277.

Binetti, M. S. (2007). Romance in the workplace: When love becomes litigation. Hofstra Labor and Employment Law Journal, 25, 153-172.

Boatright, J. (2001). Financial services. In M. Davis \& A. Stark (Eds.), Conflict of interest in the professions (pp. 217-236). Oxford: Oxford University Press.

Borden, S. L., \& Pritchard, M. S. (2001). Conflict of interest in journalism. In M. Davis \& A. Stark (Eds.), Conflict of interest in the professions (pp. 73-91). Oxford: Oxford University Press.

Bosch, J. (2003). None of your business (interest): The argument for protecting all employee behavior with no business impact. Southern California Law Review, 76, 639-662.

Bösch, F. (2015). When private life became political: German politicians, sex scandals, and mass media, 18801914. Trans-Humanities Journal, 8(3), 33-66.

Boyd, C. (2010). The debate over the prohibition of romance in the workplace. Journal of Business Ethics, 97, $325-338$.

Calhoun, C. (1995). Standing for something. Journal of Philosophy, 92, 235-261. 
Camarena, I. G. (2001). Domestically violent attorneys: Resuscitating and transforming a dusty, old punitive approach to attorney discipline into a viable prescription for rehabilitation. Golden Gate University Law Review, 31, 155-191.

Carlton, B. L. (1973). Pettit v. state board of education: Out-of-classroom sexual misconduct as grounds for revocation of teaching credentials. Utah Law Review, Winter, 797-807.

Carson, T. L. (1994). Conflicts of interest. Journal of Business Ethics, 13, 387-404.

Chadwick, K. L. (2006). Is leisure-time smoking a valid employment consideration? Albany Law Review, 70, $117-141$.

Clor, H. M. (2000). The death of public morality. The American Journal of Jurisprudence, 45, 33-49.

Cohen, C. F., \& Cohen, M. E. (2007). On-duty and off-duty: Employee right to privacy and employer's right to control in the private sector. Employee Responsibilities and Rights Journal, 19, 235-246.

Coleman, S. (2005). When conflicts of interest are an unavoidable problem. Working Paper. Australian Association for Professional and Applied Ethics: 12th annual conference 28-30 September, Adelaide.

Cranford, M. (1998). Drug testing and the right to privacy: Arguing the ethics of workplace drug testing. Journal of Business Ethics, 17, 1805-1815.

Dalton, D. R., \& Daily, C. M. (2001). Director stock compensation: An invitation to a conspicuous conflict of interests? Business Ethics Quarterly, 11, 89-108.

Davidson, J. E. (1998). Reconciling the tension between employer liability and employee privacy. Civil Rights Law Journal, 8, 145-196.

Davis, M. (2001). Introduction. In M. Davis \& A. Stark (Eds.), Conflict of interest in the professions (pp. 5-19). Oxford: Oxford University Press.

DesJardins, J., \& Duska, R. (1987). Drug testing in employment. Business \& Professional Ethics Journal, 6, 3-21.

Dobel, J. P. (1999). Public integrity. Baltimore, MD: Johns Hopkins University Press.

Donaldson, T., \& Dunfee, T. (1999). Ties that bind: A social contracts approach to business ethics. Cambridge: Harvard Business School Press.

Driver, J. (1992). Caesar's wife: On the moral significance of appearing good. The Journal of Philosophy, 89, $331-343$.

Eisenhardt, K. M. (1989). Agency theory: An assessment and review. Academy of Management Review, 14, 57-74.

De George, R. T. (2011). Business ethics. India: Pearson Education.

Geraghty, K. A. (1997). Bruising the legal profession: Attorney discipline for acts of domestic violence. Rutgers Law Journal, 28, 451-489.

Greenfield, P. A., Karren, R. J., \& Giacobbe, J. K. (1989). Drug testing in the workplace: An overview of legal and philosophical issues. Employee Responsibilities and Rights Journal, 2, 1-10.

Grossman, J. B., \& Yalof, D. A. (1998). The "public" versus the "private" president: Striking a balance between presidential responsibilities and immunities. Presidential Studies Quarterly, 28, 821-831.

Hauser, C. (2017). Lone finger at president costs cyclist her job. The New York Times, November 7, A10.

Howard, R. C., Jr. (1975). Disciplining attorneys for non-professional conduct involving alcohol and sex. Arizona State Law Journal, 411-433.

Hyman, J., Baldry, C., Scholarios, D., \& Bunzel, D. (2003). Work-life imbalance in call centres and software development. British Journal of Industrial Relations, 41, 215-239.

Jacobson, W. S., \& Tufts, S. H. (2013). To post or not to post: Employee rights and social media. Review of Public Personnel Administration, 33, 84-107.

Jennings, M. M. (2005). Does officer personal conduct matter when it comes to company ethics? Corporate Finance Review, 10, 43-46.

Kaptein, M., \& Wempe, J. (2002). The balanced company: A theory of corporate integrity. Oxford: Oxford University Press.

Kekes, J. (1983). Constancy and purity. Mind, 92, 499-518.

Kosla, M. (2001). Disciplined for bringing a sport into disrepute: A framework for judicial review. Melbourne University Law Review, 25, 654-679.

Kossek, E. E., \& Block, R. N. (1993). The employer as social arbiter: Considerations in limiting involvement in off-the-job behavior. Employee Responsibilities and Rights Journal, 6, 139-155.

Lamboo, T. (2010). Police misconduct: Accountability of internal investigations. International Journal of Public Sector Management, 23, 613-631.

Lansing, P., \& Goldman, N. P. (1996). The frequent-flier dilemma: Should the employer or the employee be the beneficiary of these programs? Journal of Business Ethics, 15, 661-670.

Lasthuizen, K., Huberts, L., \& Heres, L. (2011). How to measure integrity violations: Towards a validated typology of unethical behavior. Public Management Review, 13, 383-408.

Lindblom, L. (2007). Dissolving the moral dilemma of whistleblowing. Journal of Business Ethics, 76, 413-426.

Lippke, R. L. (1989). Work, privacy, and autonomy. Public Affairs Quarterly, 3(2), 41-55.

Lord, R. G., \& Smith, J. E. (1983). Theoretical, information processing, and situational factors affecting attribution theory models of organizational behavior. Academy of Management Review, 8, 50-60. 
Loudoun, R. (2008). Balancing shiftwork and life outside work: Do 12-h shifts make a difference? Applied Ergonomics, 39, 572-579.

Maak, T. (2008). Undivided corporate responsibility: Towards a theory of corporate integrity. Journal of Business Ethics, 82, 353-368.

MacIntyre, A. C. (1999). Dependent Rational Animals: Why human beings need the virtues. The Paul Carus lecture series 20. Chicago: Open Court Publishing.

Mael, F. A. (1998). Privacy and personnel selection: Reciprocal rights and responsibilities. Employee Responsibilities and Rights Journal, 11, 187-214.

McDonald, P., \& Thompson, P. (2016). Social media(tion) and the reshaping of public/private boundaries in employment relations. International Journal of Management Reviews, 18, 69-84.

McFall, L. (1987). Integrity. Ethics, 98, 5-20.

Meadows, W. Z. (1993). Attorney conduct in the operation of a motor vehicle as grounds for professional discipline. The Journal of Legal Profession, 18, 417-424.

Menkel-Meadow, C. (2001). Private lives and professional responsibilities: The relationship of personal morality to lawyering and professional ethics. Pace Law Review, 21, 365-393.

Miller, D. S. (1997). Off duty, off the wall, but not off the hook: Section 1983 liability for the private misconduct of public officials. Akron Law Review, 30, 325-392.

Miller, A. J. (2006). Legal aspects of stopping sexual exploitation and abuse in UN peacekeeping operations. Cornell International Law Journal, 39, 71-96.

Minkler, L. (2008). Integrity and agreement: Economics when principles also matter. Ann Arbor: University of Michigan Press.

Musschenga A. W. (2002). Integrity: Personal, moral, and professional. In A. W. Musschenga, W. van Haaften, B. Spiecker \& M. Slors (Eds.). Personal and moral identity (pp. 169-201). Dordrecht: Springer.

Nwabueze, R. N. (2009). Breach of trust as professional misconduct. Journal of Commonwealth Law and Legal Education, 7, 65-77.

Nylén, L., Melin, B., \& Laflamme, L. (2007). Interference between work and outside-work demands relative to health: Unwinding possibilities among full-time and part-time employees. International Journal of Behavioral Medicine, 14, 229-236.

Olivier, S. (2006). Moral dilemmas of participation in dangerous leisure activities. Leisure Studies, 25, 95-109.

Pagnattaro, M. A. (2004). What do you do when you are not at work: Limiting the use of off-duty conduct as the basis for adverse employment decisions. University of Pennsylvania Journal of Labor and Employment Law, 6, 625-684.

Rabin-Margalioth, S. (2006). Love at work. Duke Journal of Gender Law \& Policy, 13, 237-253.

Reiter, S. A., \& Williams, P. F. (2004). The philosophy and rhetoric of auditor independence concepts. Business Ethics Quarterly, 14, 355-376.

Rhode, D. L., \& Woolley, A. (2012). Comparative perspectives on lawyer regulation: An agenda for reform in the United States and Canada. Fordham Law Review, 80, 2761-2790.

Rowan, J. R. (2000). The moral foundation of employee rights. Journal of Business Ethics, 24, 355-361.

Sawicki, N. N. (2009). A theory of discipline for professional misconduct. Penn Law: Legal Scholarship Repository, Paper, 267, 1-36.

Schrag, B. (2001). The moral significance of employee loyalty. Business Ethics Quarterly, 11, 41-66.

Scott, E. D. (2002). Organizational moral values. Business Ethics Quarterly, 12, 33-55.

Seymore, M. L. (2003). Attorney-client sex: A feminist critique of the absence of regulation. Yale Journal of Law \& Feminism, 15, 175-223.

Sprague, R. (2011). Invasion of the social networks: Blurring the line between personal life and the employment relationship. University of Louisville Law Review, 50, 1-34.

Thompson, D. F. (1987). Political ethics and public office. Cambridge, MA: Harvard University Press.

Treviño, L. K., Den Nieuwenboer, N. A., \& Kish-Gephart, J. J. (2014). (Un)Ethical behavior in organizations. Annual Review of Psychology, 65, 635-660.

Vardi, Y., \& Weitz, E. (2004). Misbehavior in organizations: Theory, research and management. Mahwah: Lawrence Erlbaum.

Warner, D. M. (1994). "We do not hire smokers": May employers discriminate against smokers? Employee Responsibilities and Rights Journal, 7, 129-140.

Williams, B. (1981). Moral luck: Philosophical papers 1973-1980. Cambridge: Cambridge University Press.

Woolley, A. (2007). Tending the bar: The good character requirement for law society admission. The Dalhousie Law Journal, 30, 27-77.

Publisher's Note Springer Nature remains neutral with regard to jurisdictional claims in published maps and institutional affiliations. 